\title{
Elite Citizen Women and the Origins of the Hetaira in Classical Athens
}

\section{Introduction}

If you open the Liddell-Scott-Jones dictionary to look up the word hetaira, you find the definition "courtesan." The recognizable English word provides a reassuring sense of comprehension, a sense that is unfortunately false. Greek does not always translate easily into English and often readers are compelled to examine cultural, political, or sociohistorical contexts for a word before making a decision on how to trans-

Words that denote women's social statuses, however, typically do not.

Rather, LSJ, assuming that the social statuses of women are transparent and obvious, hides the complexities that surround the words applied to these women or how they are represented generally in image and text. When scholars see an image of a woman or read the name of a woman in a forum for public audiences, like comedy or oratory, they immediately make a series of assumptions about the woman's identity, including her social position, occupation, and legal status. In images, a woman is immediately deemed a prostitute, if nude, or if dressed but playing a

hetaira. The term has a basic meaning of 'companion' (on analogy with hetairos $)^{2}$ and is almost always, except in limited cases, translated as "courtesan." Courtesan is itself a vague and culturally contingent word, especially in the nineteenth century when our lexicon was produced. woman but something in between. How scholars have dealt with this ambiguity has varied, but interpretation has fallen strongly on the side of "closer to prostitute than to wife" and many scholars consider hetaira a synonym for prostitute, especially since they believe that only prostitutes from the narrative driven by these lexical assumptions. The term hetaira was used in archaic and classical Athens to designate both a status and a 
formal marriage. This use of hetaira to designate marriageability occurs only in the fourth century. ${ }^{5}$ In the late sixth century, in Athens and in some Ionian Greek poleis, I will argue that the word hetaira designates not a status but a person associated with a set of behaviors typical of the sympotic culture of the Greek elite. When scholars collapse these historically distinct uses of the term hetaira, they imagine a social world based on a strict wife-whore dichotomy. The mechanical application of this dichotomy has created basic misunderstandings of the position of some women, particularly noncitizen women, in classical Athens.

The wife-whore dichotomy underlies many approaches to women in Athens and intersects with scholars' use of the language of respectability. They typically label a woman as disreputable if she is named in the courts, on the comic stage, or appears on a sympotic imaged. It is a short step to labeling her a prostitute, which then is assumed to exclude her from the category of wife and citizen. ${ }^{6}$ Scholars identify this strong wifewhore dichotomy in a variety of ancient sources and claim that it is an unbreachable ideological barrier for the ancient Athenians. As Madeleine Henry writes, "Erotic pleasure and legitimate marriage are classified into categories of thought . . . which are firmly separated from one another." This dichotomy exists in some of the language of Athenian orators and comedy. But not every woman in Athens was either a citizen wife or a foreign prostitute in reality (or even, I would argue, ideologically). Recent scholarship has questioned this dichotomy. ${ }^{8}$ Unfortunately, these discussions have frequently started from the assumption that noncitizen women were mostly sexual laborers. Because a 'respectable woman' was separated or secluded from civic life (except in religious contexts), these noncitizen women, who might appear in public, were 'disreputable,' that is, sexualized. ${ }^{9}$ This sequence of assumptions misrepresents women and classical Athens for several reasons. First, the wife-whore dichotomy does not accurately reflect classical Athenian gender ideologies or practices. Second, the category of 'respectable' is ambiguous with respect to the behaviors and statuses attached to it. Finally, this approach privileges ideology over reality: even if an author attempts to limit a woman to the status of wife or whore, her lived experience likely defies such broad generalizations and easy categorization. ${ }^{10}$

Hetairai have been frequent victims of scholars' misleading application of the language of respectability. One issue is that it is unclear why our sources call some women hetairai. The status of those women is frequently vague. Traditionally scholars have assumed that the difference between a hetaira and a pornê was class but both were prostitutes. ${ }^{11}$ They 
assimilated a hetaira to the modern courtesan, a type of mistress or kept woman who participated in the elite social life of various periods of European history, particularly, the sixteenth through nineteenth centuries. These women were not quite prostitutes but not quite wives (though some became wives). Some were aristocrats; some were from the working poor. Their lifestyle, however, was marked by access to wealth and luxury. A courtesan socialized with the elite, ran a salon, modeled for artists, and earned a living by finding a man or men of wealth and influence to provide them with much needed income or goods or even homes. ${ }^{12} \mathrm{~A}$. W. Gomme $(1925,16-7)$ rejected the idea that there was such a class of women in classical Athens, an idea that came, it seems, both from comparisons of women like Aspasia to the courtesans of the modern world and from the projection of ideas from Second Sophistic works like Athenaeus's Deipnosophists and Lucian's Chattering Courtesans back into the fifth century BCE. The idea of a high-class prostitute known as a hetaira has persisted in scholarship, especially over the last four decades when scholarship on women's lives, and prostitution in particular, has proliferated. The figure of Neaira has loomed large in connecting the term itself with symposia and the image of the kept woman. ${ }^{13}$

Another confusion stems from an insistence on the term's consistency in use over several centuries. In particular, the hetairai of the second century CE have been conflated with the term as used in the fourth century BCE to refer to women who were undowered and without a kurios living in the city. ${ }^{14}$ These women were sometimes citizens, but were most frequently metics who had either moved to Athens voluntarily or who were freed slaves. Because they were without dowry or kurios, they were considered unmarriageable and, as such, could only be the 'companions' or 'girlfriends' of men. They were thus 'sexually available' outside of the legal bonds of marriage. Some of them likely worked as prostitutes, but not all. Their status as without a kurios (or autê hautês kuria; cf. [Dem.] 59.46 and Antiphanes, fr. 210), however, left them vulnerable, and men who mistreated them or sexually assaulted them were not accountable in law. ${ }^{15}$ This precarious status likely led some men to view them as the equivalent of prostitutes, but the term itself was not necessarily synonymous with prostitute. In addition, as I argue in this article, the term designated elite citizen women who participated in symposia and a generally luxurious lifestyle in the late sixth and early fifth centuries. When these different uses of the term are conflated and combined with social prejudice, it leads to a confusion of the women's behavior (party going) and status (unmarriageable) with one potential occupation (sexual labor), 
a prejudice that orators like Apollodorus exploited to great advantage. Neaira receives the status of autê hautês kuria by the polemarch when he resolves a dispute over Neaira's legal status between Stephanus and Phrynion ([Dem.] 59.46). Apollodorus says that she behaves like a hetaira (partygoer, 59.24), but she is legally her own kurios (and so likely unable to contract a marriage).

In what follows, I disentangle these conflations and argue that one possible origin for the term hetaira might explain the long association of hetairai with symposia, luxury, and wealth. The hetaira in this context, according to Leslie Kurke, is no different from the pornê, but was "invented" as a way of differentiating elite social practice from non-elite. Kurke situates this process of invention within the framework of habrosunê, the imitation of Eastern luxury culture by elite citizens. ${ }^{16}$ I agree with this framework, but suggest instead that the association of women known as hetairai with the symposium derives from the social habits of elite women, many of them either foreign wives or metroxenai (daughters of foreign mothers), who shared a common luxury culture with their male counterparts. These women frequently had 'bad' reputations in Athens, but they were, by most standards, established as 'respectable' citizen wives. After a discussion of sympotic culture and elite women's possible participation, I examine the lives of two historical Athenian citizen elite women who embody both the lifestyle of habrosunê and of the hetaira as our ancient sources seem to define it.

\section{Hetairai among the Citizens Elite}

Athenian elite culture found expression in the symposium, the domain of men and their erotic and political discourse. Sympotic activity excluded women, it is assumed, unless they provided some entertainment, primarily as hired sexual laborers. ${ }^{17}$ The evidence for these assumptions comes from later practice and contemporary vase imagery, where scholars confidently identify any women in a sympotic setting as an hetaira. Later practice, however, is often a poor guide to earlier behavior and there is no evidence before Herodotus of the word hetaira being used to denote a type of prostitute. ${ }^{18}$ When we examine the evidence for elite practice without the faulty assumptions, a different picture emerges of the possibilities of elite behavior in the late sixth and early fifth centuries.

In the lyric, elegiac, and epinician poetry of this period, the word hetaira never denotes a prostitute and frequently lacks eroticism. In Sap- 
pho, Leto and Niobe are hetairai (fr. 142), as are Sappho's own circle of female friends for whom she sings (poem 160). In Pindar's Pythian 3, the hetairai are the female age-mates who would have sung the bridal song for Asclepius's mother, Coronis. In Pythian 9, Pindar says of the Naiad Creusa: "She loved not the path walked to and fro before the looms, nor the pleasures of dining with her oikoriai hetairai (female house-mates)." Pythian 9 is the first text to connect the hetairai with the "pleasures of ining," perhaps a reference to symposia. ${ }^{19}$ Although it is assumed that only elite citizen men (hetairoi) dined in luxury together (in their hetairiai), our sources suggest that among elite families and some nonAthenian Greeks, women also had dinner companions and enjoyed "the pleasures of dining," and not just with household servants, but with visiting women, like female relatives and friends, and occasionally even men. ${ }^{20}$

Beyond the use of the word hetaira, readers of archaic sympotic poetry have imagined that the eroticized women were prostitutes. There is no reason, however, that these women could not be citizens and the objects of male seduction in elite discourse. ${ }^{21}$ The woman addressed as a "Thracian filly" in Anacreon, fr. 417 PMG (discussed by Kurke at length), may not a prostitute at all, but an elite girl or young woman whom the poet wishes to seduce, a foreigner girl, or a metroxenê of Thracian descent, like any number of citizen wives and daughters in the late sixth and early fifth centuries. Nothing in the poem requires her to be a prostitute. In fact, the poem suggests strongly that the girl is a parthenos rejecting any attempt to marry or seduce her. ${ }^{22}$ Sharon James $(2012,83)$ suggests that the young girl in the Cologne fragment of Archilochus is a free woman and citizen. The poem "proposes, very surprisingly, that premarital sexual activity might not destroy the reputation and life of a citizen girl." Some sympotic poems may discuss prostitutes, but we may also find elite young women who are eroticized just as their elite male counterparts were. They are kalai girls, pursued and seduced like the kaloi boys of other poems and pots. ${ }^{23}$

Women might even participate in this elite erotic discourse. Two fragmentary vases found in the Athenian Agora contain inscriptions where women record their erotic attachment to men. The first (Agora 21 C10) says, "Lycomachus seems kalos to Ianthis." The second, "Alcaeus seems kalos to Melis." ${ }^{24}$ Whereas Susan Cole $(1981,131)$ asserts that these women must certainly be prostitutes because they would otherwise not know men outside of their immediate families, these could simply be 
elite women who admired certain young men. These kalos inscriptions fit elite discourse, which elite women may have accessed more readily than women of the lower classes.

We must remember two important points in order to understand the role of elite women in the archaic symposium. First, not all Greeks shared Athenian values concerning the separation of the sexes and, second, foreign marriages and influence were not uncommon among the Athenian elite in the late archaic to early classical periods. The Athenian elite frequently married women from Miletus, Eretria, the Black Sea settlements, and Thrace, all of which were associated in antiquity with less strict gender divisions and where elite women were more integrated into social activities of dining and drinking. Miletus, where a large number of immigrants to Athens of elite status came from, was known in antiquity for its luxury-loving hedonism. ${ }^{25}$ The influence of the Near East, specifically Lydia, is considered an important source of these behaviors and the accompanying luxuries. ${ }^{26}$

This lifestyle was widespread among the Ionians. Aside from the lyric poetry of the archaic period (such as that of Sappho), the Clazomenian sarcophagi from Acanthus in Chalcidike (ca. 540-500 BCE) are important evidence. The image on one side of one of the tombs shows banqueters, men and women together, sharing couches. Some of their heads are covered in extravagant head-wraps (sakkoi), considered Lydian in style. ${ }^{27}$ Both Jan Paul Crielaard and Joseph Skinner remark that the presence of the women at the banquet image on the sarcophagus (in addition to the head-wraps) suggests that this is an Eastern-inspired scene, a sign of internationalism or cosmopolitanism instead of orientalism. ${ }^{28}$ The presence of the women, though, is especially troubling to Skinner, who, like Crielaard, suggests that the identity of the women was "ambiguous since, by conventional standards and with obvious exception of hetairai and slaves, women did not attend symposia." ${ }^{29}$ It is more likely that these Greeks simply did not follow conventional standards of their Athenian neighbors any more than the Etruscans seem to have done or, possibly, the Locrians. ${ }^{30}$ In fact, the art of Eturia represents precisely the aristocratic practices that, I argue, some Athenian households in the late sixth and the early fifth century participated in. ${ }^{31}$

Throughout the sixth and fifth centuries, many elite Athenian families married women from Ionian cities and participated in the international culture of these cities and owned property in regions where this lifestyle was more common. Many Athenians of all social classes had access to what were considered Eastern goods and practices, especially 
styles of dress, hair styles, and adornments from the Persian Empire that were considered accessible marks of luxury. ${ }^{32}$ We should consider that the practice of shared dining and drinking was more widespread than a handful of condemnations from the late fifth or fourth centuries suggest they were. ${ }^{33}$ As Kelly Blazeby (2011) shows, whether it was considered decent for men and women to dine and drink together in some texts does not mean that men and women did not dine and drink together, nor does it mean the women who did so were prostitutes. ${ }^{34}$ The nomoi of these foreign women were foreign just as the nomoi of some Athenian elites were considered foreign and were condemned at times as "undemocratic.' 35 This may be one reason why some women were slandered in public by political enemies of their families, as we will see in the case studies discussed below. It was among the elite that we see the most evidence in fifth-century material remains of the adoption and adaptation of Lydian and Persian practices and lifestyle. ${ }^{36}$ If we reconsider the hetaira as originally a name used to refer to elite women, sometimes of foreign birth, who participated in sympotic and luxury culture, the appearance of these women in both sympotic and political discourse makes more sense, as does the way we have come to identify hetairai as foreign women of renown, wealth, education, and access to the political elite. It was only over time that their behavior and lifestyle came to be associated with prostitutes or other women who shared or even imitated the behaviors of these elite women but did not share their citizenship or social position.

\section{Elite Citizen Hetairai?}

We find two women in our sources whose lifestyle and backgrounds reflect the contexts described above: Elpinice and Coisyra. These women were members of the most elite citizen families in Athens and both lived at a time when the line between Athenians and other Greeks (and even non-Greeks) was less pronounced and when evidence of foreign influence among the citizen elite was pervasive. Elpinice and Coisyra exhibit hetairai-prostitutes of later texts if we did not know that they were married citizen women. Elpinice's father was the Athenian general Miltiades, Thrace-a real 'Thracian filly.' Was she wealthy? Absolutely. Did she 
Did she have a distinguished or famous name of her own that is used in public fora? This list is long. She was accused publicly of having incestuous relations with her brother (Eupolis, Poleis fr. 221 A-K, Kock 208; and then repeated by [Andocides.] 4.33; Plutarch, Cim. 4.8-9; Athenaeus 13.589e8-f2 paraphrasing Antisthenes) and to have offered herself sexually to Pericles to effect her brother's return from exile (Athenaeus 13.589e8-f2; Plutarch, Per. 10.5-6 and Cim. 14.5, attributed originally to Steisimbrotus, FrGH 107 F 5). ${ }^{37}$ She is also said to have questioned publicly Pericles' leadership during the Samian War at the annual funeral oration (Plutarch, Per. 28.5-7). It is true that these references are probably all from the period after her death, which scholars typically claim to be the only time a non-prostitute 'respectable woman' was named in public. ${ }^{38}$ But these instances of public naming and criticism may reflect what was said in her own lifetime, a thesis supported by her appearance on an ostrakon (Kerameikos O 6874), ca. 480 BCE. (Fig. 1). This ostrakon

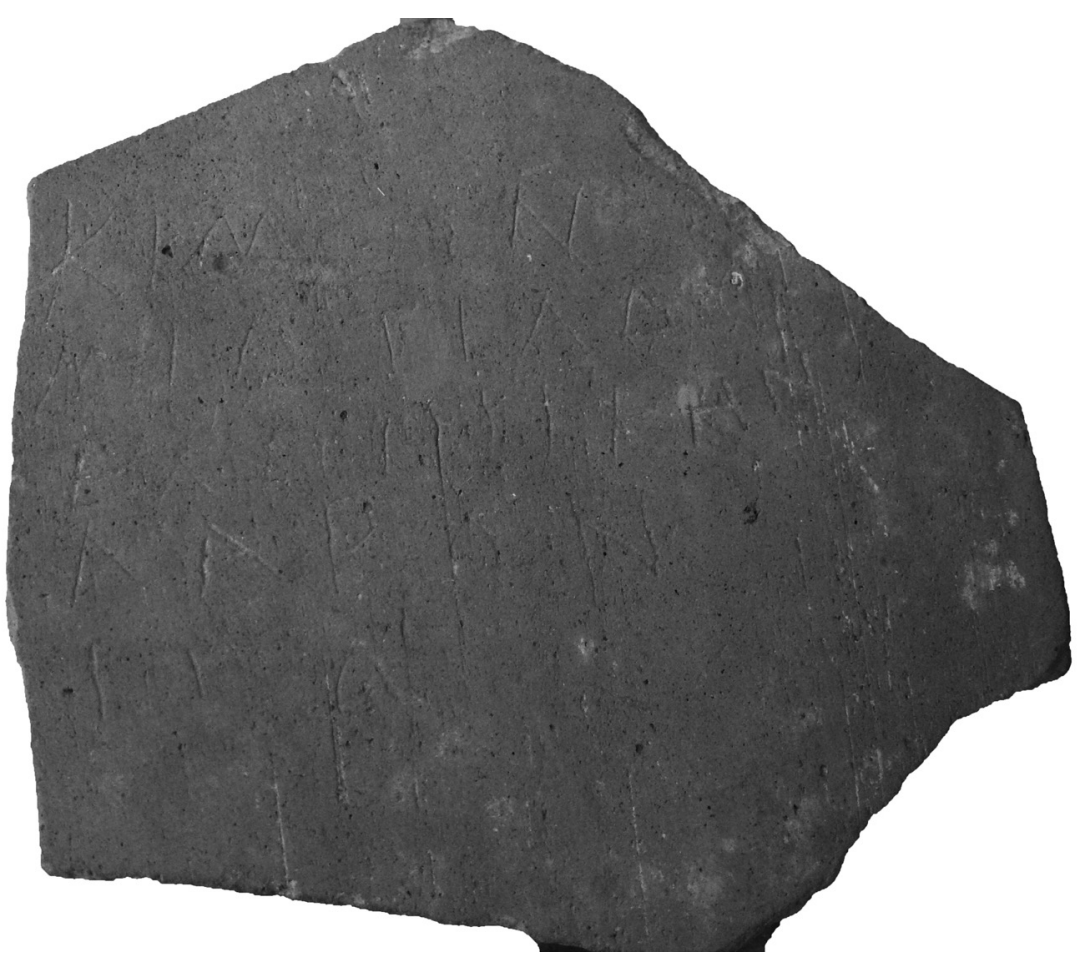

Figure 1. KIM $\Omega$ N MI $\Lambda$ TIA $\triangle O Y$ E $\Lambda \Pi I N I K H N \Lambda A B \Omega N$ ITS (Kimon, son of Miltiades, take Elpinice and go). Kerameikos O 6874. Photo by Rebecca Kennedy 
undisputedly positions her as a publicly well-known figure and, presumably, a woman of ill-repute. As Stefan Brenne (1994, 13) argues, ostraka did not simply function to list names, but also served to condemn, mock or defame the individuals who appeared on them. A number of ostraka, such as the Elpinice ostrakon, share characteristics with personal attacks and invective from the comic stage-one of the public fora where supposedly only 'non-respectable' women are named-and with iambic.

We do not know whether Elpinice was an intellectual or educated; she was wealthy enough to have been educated. We do, however, have evidence that Elpinice was associated with performance or modeling. She supposedly modeled for and had an affair with the painter Polygnotus (Plutarch, Cim. 4.6) while married to Callias. We are told that Polygnotus painted her image into the Stoa Poikile and Cnidian Lechê paintings of the Sack of Troy, even going so far as to alter the myth slightly to include her in the Athenian version (Plutarch, Cim. 4.7). ${ }^{39}$ It seems also that Polygnotus included a representation of Elpinice herself on one vase; her name at one time was visible above the seated woman shown playing the aulos (Fig. 2) ${ }^{40}$ Elpinice had a number of associations linking her to Polygnotus in ways that suggest it was popular gossip. ${ }^{41}$ It is also

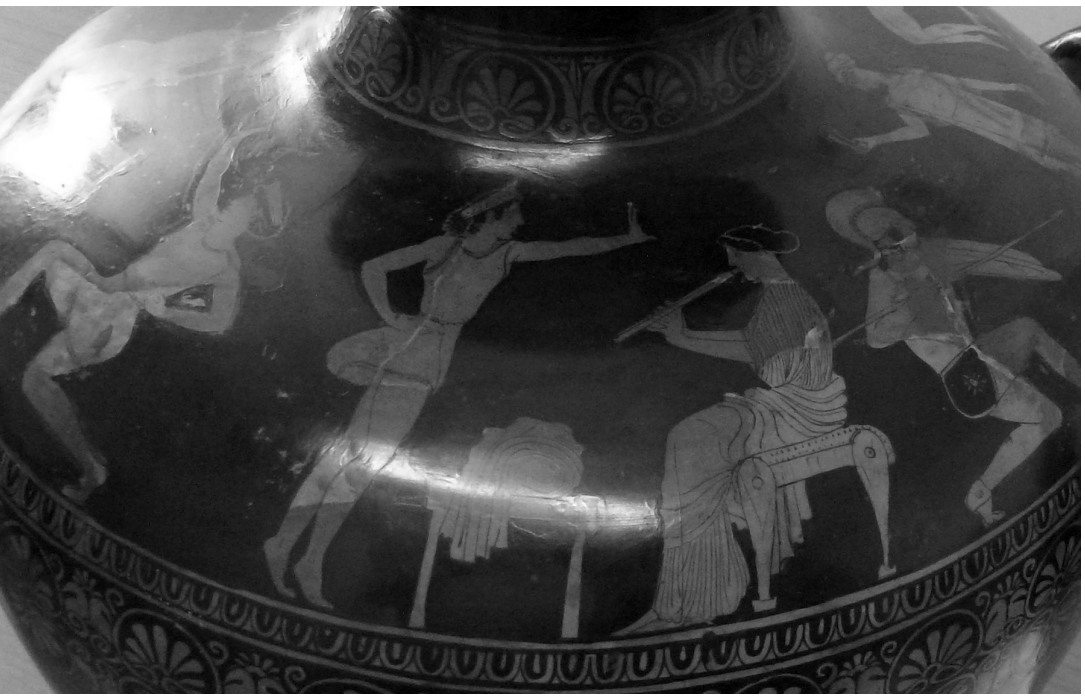

Figure 2. Music or Dance school with "Elpinice" once inscribed over the seated 
likely that she was considered 'respectable,' given her aristocratic status and family connections; it is even possible that there was a statue of her garbed as a matron, dedicated on the Acropolis by her husband Callias. ${ }^{42}$

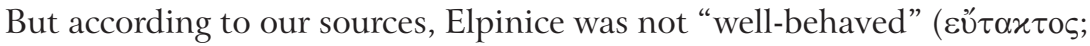
Plutarch, Cim. 4.6) and as the heavily eroticized anecdotes mentioned earlier show, she acted like the hetairai of fourth-century oratory rather than a citizen wife. And she may have been called a hetaira in the sense that she was a female hetairos. She was an elite women who was associated in the minds of the Athenian public with luxury, sexuality, and the sympotic lifestyle. But she was not a prostitute.

Elpinice was not alone in her behavior or reputation. Coisyra was an older contemporary of Elpinice and her extravagant behavior was even more notorious. Who was Coisyra? Until the 1960s, she was considered a comic fantasy, a woman made up in order to represent the luxury and arrogance of elite women. But then her name showed up on a handful of ostraka. As with Elpinice, the appearance of Coisyra on these ostraka demonstrates her public notoriety. In at least two of the ostraka, she is listed as the mother of Megacles and wife of Hippocrates (Fig. 3). ${ }^{43}$ Brian Lavelle (1989) has reasonably conjectured that she was the daughter of

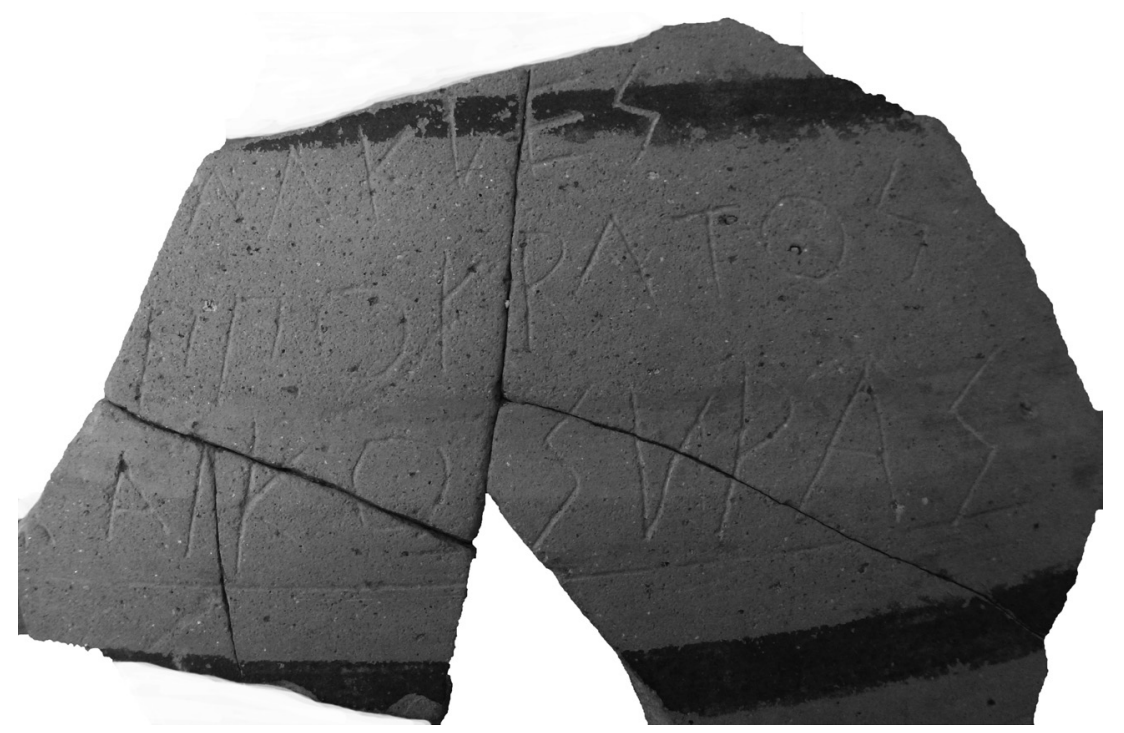

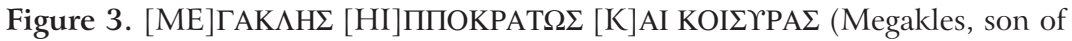
HippoCrates and Coisyra). Kerameikos Ostraka (unpublished). Photo by Rebecca Kennedy. 
Peisistratus and an Eretrian noblewoman also named Coisyra (an Eretrian name); her daughter was probably Agaristê, mother of Pericles. ${ }^{44}$ So synonymous did Coisyra become with the idea of luxury and high living that Aristophanes uses a verbalized version of her name, $\dot{\varepsilon} \gamma \varkappa \varepsilon x 01 \sigma v \varrho \omega-$ $\mu \varepsilon \dot{v} \eta$ (Coisyrafied, Nub. 48) and her name itself to characterize Strepsiades' wife and son as extreme lovers of luxury (Nub. 799-800). ${ }^{45}$ As Virginia Hunter $(1990,317)$ reminds us, one of the best and easiest ways to attack a man was through his mother, whose citizen status was significantly easier to question than a father's would be. ${ }^{46}$ The scholia on these passages in Aristophanes' Clouds, as well as on Archarnians 614-8, where Coisyra's name also appears, call Coisyra and her son Megacles either slaves or runaway slaves, ${ }^{47}$ something readers of oratory might recognize as a standard line of attack against political opponents, used frequently to help prove someone was not a citizen. ${ }^{48}$ Coisyra also had a semblance of respectability as a member of two of the most elite citizen families in Athens. ${ }^{49}$ But that semblance was countered by her public reputation, a reputation not unlike that of Elpinice, though less eroticized as far as we know, and perhaps the product not only of her luxurious way of life, but also of her status as the daughter of the tyrant Peisistratus and wife of an Alcmaeonid. ${ }^{50}$

\section{Conclusion}

Elpinice and Coisyra suggest that Athens in the late sixth to the midfifth century contained elite women living a lifestyle not unlike their male aristocratic counterparts. They likely attended symposia, indulged

in fine food and wine, paraded about dressed like Lydian or Persian nobles. These women were publicly notorious, if not scandalous, but they were neither prostitutes nor courtesans. ${ }^{51}$ The gossipy anecdotes about them describe behavior that resembles the definition of the hetaira reconstructed by scholars from the orators and later writers like Athenaeus. But this was also a period when the elite culture of habrosunê became the target of negative criticisms. This negative turn resulted from two factors: first, the Persian Wars and its subsequent anti-Eastern rhetoric, and second, a turn toward isonomia and the connecting of luxury with tyranny and hubris as the Athenians democratized more thoroughly. ${ }^{52}$ Elpinice and Coisyra were caught up in the politics of these events even though they were citizen wives, 'respectable' women. This makes them interesting case studies for understanding the evolution of the term het- 
not 'respectable' or are prostitutes. In the case of Elpinice, this is simply untrue. Instead, the naming and shaming of women in public fora formed part of political discourse and was not uncommon, even if it was not respectful. ${ }^{53}$ 'Respected' and 'respectable' are not quite the same thing. ${ }^{54}$ And the expected public roles for women, such as at funerals, suggests that attempts to silence women, especially aristocratic women, were linked to the politics of the city and not social mores. ${ }^{55}$ The female relatives of prominent politicians were fair targets for public naming and shaming, and neither Elpinice nor Coisyra were exempt. If we had orations from the first half of the fifth century, we would likely find citizen women named in the courtroom invectives of the day as part of politics as usual, women who might have endured challenges to their citizen status (perhaps even their status as free persons) and talk of their supposed sexual activities and indulgences, much like we see in fourthcentury oratory. In fourth-century oratory, women of lower status than Elpinice and Coisyra found their status and relations under similar attack, with an emphasis on their luxury-loving behavior. This lifestyle is the mark, in fact, of their low status and threat to the polis; these women were not said to have acted like a Coisyra, but to have acted hubristically. $^{56}$ The proverbial associations of Coisyra with luxury and tyranny, however, seem to have extended well into the fourth century. The original citizen elite hetaira became the model for the noncitizen prostitute hetaira.

This conclusion compels us to reconsider the connections we make between hetairai, symposia, and prostitution. If we accept that elite women like Elpinice and Coisyra participated in sympotic culture and that women generally were subject to eroticization, then the question about what a hetaira is changes. No longer do we ask, "What type of prostitute was a hetaira?," but "How did hetairai come to be associated with prostitution?" The answer can only be found by trying to deconstruct the prejudices that surrounded these women instead of assuming the term hetaira was an unproblematic job description. The word hetaira, when it appears, cannot always be translated as "prostitute" or "courtesan," nor is the behavior of a woman or the appearance of her name in oratory or comedy enough to decide her social status and occupation. We should not take at face value the accusations and narratives of the orators when they attack a woman. The term hetaira, as its trajectory in the later fifth century and beyond shows, was likely used as a slander against any woman whose behavior was considered scandalous on some level, women who were considered by their social superiors to be sexually 
available to them. Such scandalous behavior could have included simply being poor and without male family. It may have been attached in the early fifth century to prostitutes who attended symposia, as a slur on elite women like Elpinice and Coisyra. The term was intentionally ambiguous, which requires us to be more thoughtful and cautious in viewing it as a distinctive status category. ${ }^{57}$ When we consider real women who were not prostitutes, but who exhibited the behaviors we associate with it and when we scrutinize the category of the hetaira, we open up additional avenues of inquiry into the lives of women in Athens in the classical period, especially those women for who have traditionally been deemed prostitutes. ${ }^{58}$

2

3

4

5

6

7

8

9

10 
Glazebrook, A. 2005. “The Making of a Prostitute: Apollodoros's Portrait of Neaira." Arethusa 38: 161-87.

. 2006. "The Bad Girls of Athens: The Image and Function of Hetairai in Judicial Oratory." In Faraone and McClure 2006, 125-38.

- 2012. "Prostitutes, Plonk, and Play: Female Banqueters on a Red-Figure Psykter from the Hermitage." CW 105: 497-524.

— and M. Henry, eds. 201 la. Greek Prostitutes in the Ancient Mediterranean, 800 BCE-200 CE. Madison.

. 201 lb. "Introduction." In Glazebrook and Henry 201 la, 3-13.

Gomme, A.W. 1925. "The Position of Women in Athens in the Fifth and Fourth Centuries" CP 20: 1-25.

Griffith, M. 1995. "Brilliant Dynasts: Power and Politics in the 'Oresteia."' CA 14.1: 62-129.

Hardwick, L. 1993. "Philemon and Pericles: Silence in the Funeral Speech." G\&R 40: 147-62.

Henry, M. 1985. Menander's Courtesans and the Greek Comic Tradition. Frankfurt am Main.

Hickman, K. 2004. Courtesans: Money, Sex and Fame in the Nineteenth Century. London.

Hobden, F. 2013. The Symposion in Ancient Greek Society and Thought. Cambridge.

Hölscher, T. 1973. Griechische Historienbilder des 5. und 4. Jahrhunderts. Würzburg.

Hunter, V. 1990. "Gossip and the Politics of Reputation in Classical Athens." Phoenix 44: 299-325.

Izzet, V. "Etruscan Women: Towards a Reappraisal.” In James 2012a, 66-77.

James, S. 2012. "Sex and the Single Girl: The Cologne Fragment of Archilochus." In James 2012a, 81-3.

James, S., ed. 2012a. A Companion to Women in the Ancient World. Malden. 81-3.

Kebric, R. 1983. The Paintings in the Cnidian Lesche at Delphi and Their Historical Context. Leiden.

Kennedy, R. F. 2014 Immigrant Women in Athens: Gender, Ethnicity, and Citizenship in the Classical City. New York.

Keuls, E. 1993. The Reign of the Phallus. Berkeley.

Kreilinger, U. 2006. "To Be or Not to Be a Hetaira: Female Nudity in Classical Athens." In S. Schroer, ed., Images and Gender: Contributions to the Hermeneutics of Reading Ancient Art. Göttingen. 249-61.

Kurke, L. 1992. "The Politics of Habrosunê in Archaic Greece." CA 11: 91-120.

1997. "Inventing the Hetaira: Sex, Politics, and Discursive Conflict in Archaic Greece." CA 16: 106-50.

Kushner, N. 2014. Erotic Exchanges: The World of Elite Prostitution in Eighteenth-Century Paris. Ithaca.

Lang, M. 1976. Graffiti and Dipinti. The Athenian Agora, 21 . Princeton.

Lavelle, B. 1989. "Coisyra and Megacles, the Son of Hippokrates." GRBS 30: 503-13.

Lewis, S. 2002. The Athenian Woman: An Iconographic Handbook. London and New York. McClure, L. 2003. Courtesans at Table: Gender and Greek Literary Culture in Athenaeus. London and New York.

Miller, M. 1997. Athens and Persia in the Fifth Century BC: A Study in Cultural Receptivity. Cambridge. 
Pomeroy, S. 1994. Goddesses, Whores, Wives and Slaves. New York. 1

Pritchard, D. "The Position of Attic Women in Classical Athens.” G\&R 61: 174-93. 2

Redfield, J. 2003. The Locrian Maidens: Love and Death in Greek Italy. Princeton. 3

Reinsberg, C. 1989. Ehe, Hetaerentum, und Knabenleibe im antiken Griechenland. Munich.

Rounding, V. 2004. Grandes Horizontales: The Lives and Legends of Four Nineteenth-Century
Courtesans. London.

Rusten, J., ed. 2011. The Birth of Comedy: Texts, Documents, and Art from Athenian Comic 6

Competitions, 486-280. Baltimore.

Schaps, D. 1977. "The Woman Least Mentioned: Etiquette and Women's Names." 8

CQ 27: 323-30.

Shear, T. L. 1963. "Coisyra: Three Women of Athens.” Phoenix 17: 99-1 12.

Skinner, J. 2012. The Invention of Greek Ethnography: From Homer to Herodotus. Oxford.

Sommerstein, A. 1980. "The Naming of Women in Greek and Roman Comedy." QS 11: 393-418.

Stafford, E. 2013. "From the Gymnasium to the Wedding: Eros in Athenian Art and Cult." In E. Sanders, C. Thuminger, C. Carey, and N. Lowe, eds., Eros in Classical Greece. Oxford. 175-208.

Stroup, S. 2004. “Designing Women: Aristophanes's Lysistrata and the 'Hetairization' of the Greek Wife." Arethusa 37: 37-73.

Sutton, R. 1992. "Pornography and Persuasion on Attic Pottery." In A. Richlin, ed., Pornography and Representation in Greece and Rome. Oxford. 3-35.

Topper, K. 2012. The Imagery of the Athenian Symposium. Cambridge.

Vout, C. 2013. Sex on Show: Seeing the Erotic in Greece and Rome. Berkeley.

Wecowski, M. 2014. The Rise of the Greek Aristocratic Banquet. Oxford.

West, M. 1993. Greek Lyric Poetry: Translated with Introduction and Notes. Oxford.

\section{Notes}

1. The exception is Lewis 2002 which argues forcefully for a reevaluation of this position. For other recent reevaluations of women on vases, see Kreilinger 2006, Blazeby 2011, Glazebrook 2012, Topper 2012, and Vout 2013.

2. This is generally viewed as correct; see Dover 1978, 20-1. Davidson (2006, 35-6) disagrees with Dover's etymology and instead derives hetaira from hetaros, with hetairos being derived from the feminine. This, however, makes it less likely that the term's early usage was as a slur on women. Wecowski $(2014,34)$ asserts that the word hetaira is feminized from hetairos because the women participated in the same activities at the symposium. These women, however, are definitely prostitutes for him.

3. It has been more common to use courtesan in the past, but Rusten (2011) simply uses "prostitute" or even "whore."

4. E.g., Corner 2012, which argues to reaffirm the connection between symposia and women who are not 'respectable.' Davidson $(2006,36)$ includes married women available for adultery under his definition of hetaira, thus using a definition of 'respectable' that denotes behavior, not status. Wecowski (2014, 33 note 50) states that Corner "rightly" rejects any attempts to allow 'respectable' women at a symposium. He also conflates 'not respectable' and prostitute.

5. Kennedy 2014, 112-7.

6. The issue seems to be that most scholars conflate citizen and wife. This is likely

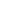
列 (1)

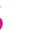
8 
a result of conflating the Citizenship Law of 451 BCE with a ban on marriage between citizen and foreigner. It is unclear whether the citizenship law actually banned marriage; see Kennedy 2014, 12-25. On the way Apollodorus constructs Neaira's identity in [Dem.] 59 through this exclusionary tactic, see Glazebrook 2005 and below in this paper.

7. Pomeroy's famously title Goddesses, Whores, Wives, and Slaves is not the beginning of this dichotomy, but has been widely influential in maintaining it. Keuls 1993 is premised on this ideological divide being absolute and strictly enforced in reality.

8. A recent example of such an approach is Gilhuly 2009, which argues for a "matrix" that includes on an ideological continuum prostitutes, wives, and "ritual performers" whose public status complicated their respectability.

9. Priestesses held an ambiguous position in this regard; see Faraone 2006 and Gilhuly 2009. For a general overview of citizen women in classical Athens, see Pritchard 2014.

10. There are dangers, as Kurke $(1997,107)$ points out, to taking texts as straightforward reflections of reality, but the extensive focus on ideology has led to the disappearance of women themselves from the history of women. They have become a series of discourses with no connection to real life.

11. See Kurke 1997 note 3 and the introduction to Glazebrook and Henry 201 lb, 4-5 for references to earlier scholarship upholding this view. Both Kurke and Glazebrook and Henry view the distinction as false.

12. There has been a great deal of interest in the great age of courtesans in recent years. Some informative reads include Hickman 2003, Rounding 2003, and Kushner 2014. On courtesans in Italy and East Asia, see also Feldman and Gordon 2006.

13. See, however, Glazebrook 2005 and 2006 on hetaira as a derogatory term and association with the symposium as negative.

14. For a discussion of these women, see Kennedy 2014, 97-122.

15. One passage often used to demonstrate that hetaira meant prostitute is Menander, Dys. 57-68. In that passage, however, the young man is not calling the girl a prostitute. He is saying that he could rape a girl of hetaira status because there would be no accountability, and in law, this was true. A woman without a kurios did not have legal recourse in the courts for certain crimes against her even if she was a metic with a prostates; see Kennedy 2014, 97-106.

16. Kurke (1992 and 1997) has discussed both hetairai and habrosunê extensively.

17. For a discussion of the sexual status of female entertainers at symposia, see Goldman in this volume.

18. These vases are typically dated between 525-475 BCE. It is not until the fourth century that texts make any explicit link between drinking at symposia and the word hetaira, the most explicit being [Dem.] 59, Against Neaira; see Kennedy 2014, 103-14.

19. There is a conjectured use of hetaira at Bacchilydes 13.57. It is not possible to associate that use with prostitution.

20. See Burton 1998 on women's commensality. Corner (2012) rejects Burton's arguments because "only prostitutes attended symposia," stated without argument.

21 . For the eroticization of women in wedding images on vases from the second half of the fifth century, see Sutton 1992 and Stafford 2013.

22. Kurke (1997, 113-4) bases her assessment that the woman is a prostitute on 
the first-century CE commentator Heracleitus's statement that the girl's attitude is "hetairic." Further proofs: the girl is Thracian and she is compared to a horse playing in the meadows, which Gentili (cited in Kurke 1997, 114 note 20) claims "suggests a woman who is sexually free and promiscuous." Kurke herself acknowledges in a note that the language of the poem is applicable to a parthenos. The association of parthenoi and frolicking in fields dates back to Nausicaa in Homer's Odyssey and also Persephone in the Homeric Hymn to Demeter.

23. On the extensive use of kalos in sympotic contexts, see Dover 1978, 111-24 and Davidson 2009, 352-6.

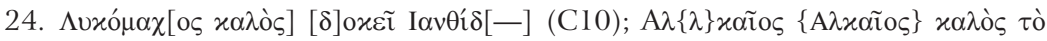

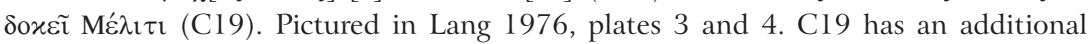

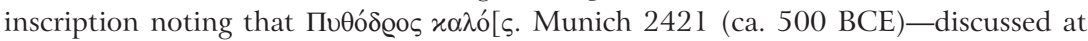
Kurke 1997, 135-6 on ARV 2 23.7, Para 323, Addenda ${ }^{2}$ 155; pictured in Reinsberg 1989, Fig. 61-is also typically thought to show prostitutes. It shows an older man admiring the kalos Euthymides on the hydria proper while two female symposiasts, naked from the waist up and playing kottabos, say, "I cast for you, kalos Euthymides." There is no need, however, to attribute a specific status to the women to understand the vase.

25. Crielaard 2009, 57-63 for sources and discussion.

26. Xenophanes, fr. 210, is a key passage; see Kurke 1992. Other examples are the Etruscans and the Locrians of southern Italy, whose iconography of men and women dining together has often led scholars (and some ancient Greeks and Romans as well) to accuse them of sexual deviancy and of prostituting their wives and daughters; see, e.g., Theopompus, Hist. 115 (FGrHist F204).

27. See Crielaard 2009, 62 for image. Lydian dress should not be assumed to indicate foreign prostitution in any image since such adornment was not restricted to either noncitizens or to one class or type of woman. The sakkos, for example, is worn by citizen and noncitizen women alike on grave stele. As Miller $(1997,153)$ remarks, "In many a system of fashion incorporation of 'exotic' elements plays a significant role, but they are never so emphatic as to disguise the wearer as a member of the alien culture."

28. Crielaard 2009, 61. Similarly, Getty 86.A3.293 (ca. 480-470 BCE), a komos scene by the Briseis painter, shows men and women both dressed in the more voluminous garments of Eastern influence as well as Lydian-style head wraps on both men and women.

29. Skinner 2013,94 . He refers to a story at Herodutus 5.18-20, where the son of the Macedonian king Amyntas becomes angered at Darius's envoys who requested that the wives of the Macedonians dine with them, though it was not Macedonian custom. Macedonian practice should not be conflated with general Greek practices. See also Herodotus 1.146, where the practice of husbands and wives not dining together in certain Ionian cities was explained as a reaction to the murder of the Carian families of the first wives of the Greek colonists who settled the cities.

30. On the Locrians, see Redfield 2003, 201-307.

31. See Bonfante 1981 on Etruscan couples and its meaning in art; also pp. 166-9 esp. on the relationship to Greek aristocratic mores. For a reassessment of Etruscan women generally, see Izzet 2012.

32. See Miller 1997, 63-88 on Persian goods in fifth-century Athens. Miller traces 